\title{
ETYKA PERSONALISTYCZNA I POCZWÓRNY ARGUMENT A ETYKA DYSKURSU
}

- Mariola Flis -

Jeśli przyjmiemy za Paulem Ricoeurem, że centralnym składnikiem moralności jest obowiązek, czyli norma po prostu, a etyka to tyle, co intencja teleologiczna nakierowana na innych, wyrażona hasłem: „żyć dobrze wraz z drugim i dla drugiego"1, wówczas moralność jawi się jako uogólniony, społecznie zobiektywizowany i zewnętrzny wobec jednostki zespół powinności indywidualnych i autonomicznych. Jeśli tak, to moralność wyznacza zachowania człowieka jako członka społeczeństwa, podczas gdy etyka konstytuuje jego indywidualne sumienie. Tak więc moralność stanowi sferę zewnętrznej, strukturalnej determinacji jednostki, której funkcjonowanie wyznacza między innymi zasada wzajemności, podczas gdy etyka jest polem jej wewnętrznej wolności i dziedziną nieskrępowanych wyborów, także niewspółmiernych skal wartości i konstruowania tożsamości.

W obszarze etyki mamy do czynienia z wieloma stanowiskami, które pozostają w niedającym się rozstrzygnąć sporze. Jedną z przyczyn tego stanu jest koncepcja natury ludzkiej. Należy podkreślić, że wkraczamy w różnokierunkowe tendencje myślenia o człowieku. $Z$ jednej strony poszukiwano jego natury i niezmiennej istoty, z drugiej wskazywano na historię jako konkretną rzeczywistość człowieka i zarazem narzędzie odpowiedzi na pytanie, kim on jest. Ten spór sprowadza się do pytania: czy człowiek ma naturę czy historię?

Myślę, że z różnorodności i pluralizmu powstałych w dziejach filozofii obrazów człowieka, można wywieść odpowiedź, iż człowiek ma naturę uwikłaną w historię, a oddziaływanie „istotowej” koncepcji człowieka było i jest silniejsze niż historii.

Początki nauk społecznych są tego najlepszym dowodem. Nie jest przypadkiem fakt, że ich powstanie i rozwój przypada na drugą połowę wieku XIX. Był to czas dominacji kierunku nazwanego ewolucjonizmem, w obszarze którego najważniejszą tezą było założenie o tożsamości ludzkiej natury. Ewolucjoniści spo-

\footnotetext{
${ }^{1}$ Ricoeur [1991] s. 37.
} 
łeczni nie twierdzili, że jesteśmy tacy sami, lecz że w tym wielkim zróżnicowaniu musi być coś, co nas łączy, co stanowi arche, czyli prazasadę. Ową prazasadę stanowią ich zdaniem uniwersalne zasady funkcjonowania ludzkiego umysłu.

Czym są te zasady? Do dzisiaj nie ma na to pytanie jednej i zadawalającej odpowiedzi. Twórca teorii ewolucji społecznej - Herbert Spencer - uważał, że jest to użyteczna hipoteza robocza, bowiem ewolucja społeczna, tak jak ewolucja biologiczna, jest postrzegana jako proces różnicowania i jej rezultatem są nowe formy społeczeństwa. Podstawę tego procesu stanowią uniwersalne zasady funkcjonowania ludzkiego umysłu, który w trakcie swojego indywidualnego rozwoju absorbuje elementy otaczającej go kultury, posługując się genetycznie określonymi regułami.

W sporze o biologiczne uwarunkowanie kultury można wskazać na dobór płciowy jako istotny mechanizm ewolucji ludzkiego umysłu. Jerzy Dziki w książce Dzieje życia na ziemi pyta: „Co skłoniło przodków człowieka do dwunożności”? W odpowiedzi podkreśla, że:

(...) dokonało się to przed znaczącym wzrostem mózgu w linii człowiekowatych, przyczyna musiała więc być natury biologicznej, a nie kulturowej. Stało się to mniej więcej wtedy, kiedy w wyniku rozwoju ryftu zaburzony został stabilny układ stosunków środowiskowych i rozpoczęło się stepowienie południowowschodniej Afryki. Zmusiło to zamieszkujące te okolice małpy człekokształtne do zmiany strategii rozrodczej. (...) Musiało więc dojść do specjalizacji funkcji pomiędzy płciami, czyli rozbieżnej ewolucji wyrażającej się nie tyle $\mathrm{w}$ dymorfizmie anatomicznym, co $\mathrm{w}$ odmiennym zachowaniu. (...) Dokonało się to zapewne w wyniku stosunkowo prostej ewolucyjnej zmiany działania czynników hormonalnych. (...) Powstał więc ewolucyjnie system krzyżujących się odruchów altruistycznych w obrębie grupy, złożonej z samca, samicy i potomstwa. Nazywamy je miłością, a grupę rodziną. ${ }^{2}$

Powyższa argumentacja wystarcza do przyjęcia tezy, że dobór płciowy był i chyba nadal jest istotnym czynnikiem ewolucji ludzkiego umysłu. Do dziś nie ma zadowalającej odpowiedzi na pytanie: czym jest umysł człowieka? W jakiej relacji pozostają i jakie są pola znaczeniowe takich pojęć jak: mózg, umysł, świadomość, myślenie?

Na te pytania też nie ma prostych odpowiedzi. Pozostając w konwencji biologicznych uwarunkowań kultury można powiedzieć, że ewolucja biologiczna

2 Dziki [2003] s. 430-431. 
wyłoniła ewolucję społeczną, a ta wykreowała myślenie abstrakcyjne. Abstrakcja jest jedną z reguł umysłu i zdaniem Piotra Lenartowicza - polega na koncentrowaniu uwagi świadomości na tym, co podobne. „Zmysły dostarczają materiału bardzo różnorodnego. Umysł przeprowadza w tym materiale selekcję, grupując razem to, co podobne, a pomijając to, co niepodobne. Elementy podobne umysł łączy razem w coś, co nazywamy pojęciem"3. Zatem abstrakcja umysłowa ukazuje rzeczywiste pokrewieństwo na pozór różnych zjawisk i przypomina metaforę. Każda metafora ujawnia „intuicyjną percepcję podobieństwa w różnorodności"4. Metafora wyposaża myśl abstrakcyjną, pozbawioną danych naocznych, w intuicje pochodzące ze świata zjawisk, których funkcją jest zapewnienie realności naszym pojęciom. Metafora dokonuje przeniesienia, przejścia od jednego stanu egzystencjalnego, jakim jest myślenie, do innego, jakim jest bycie zjawiskiem wśród zjawisk, a to może się dokonać jedynie przez analogie. $Z$ tego właśnie powodu ewolucjoniści w naukach społecznych wierzyli, że istnieją uniwersalne zasady funkcjonowania ludzkiego umysłu, które stanowią podstawę różnorodności kultur.

\section{MYŚLENIE I DZIAŁANIE}

W filozofii te zasady nazwano myśleniem, a samo myślenie zostało uznane za zasadę systemową. Myślenie i działanie są podstawowymi formami realizacji człowieczeństwa. Zatem podstawową relacją $\mathrm{w}$ obszarze uniwersalnych zasad funkcjonowania ludzkiego umysłu jest relacja między myśleniem i działaniem, którą Florian Znaniecki oddał taką formułą: „każde działaniem jest myślą" i „każda myśl jest działaniem" ${ }^{5}$. Działanie bowiem zachodzi tylko tam, „gdzie przebieg idealny jest czynnikiem wywołującym i organizującym fakty realne"6. Jest zatem działanie procesem myślowym, który powoduje konsekwencje fizyczne, czyli jest takim aktem idealnym, który wywołuje realne skutki w świecie zewnętrznym dostępnym dla doświadczenia innych podmiotów.

W tym kontekście pojawia się pojęcie racjonalności. W czasach postmitycznych i postnowoczesnych, to nauka przejęła rolę najwyższej zasady sterującej działaniem. Wyrazistą egzemplifikacją tej tezy jest scjentyzm rozumiany jako filozoficzna wiara nauki w samą siebie. Jest to stanowisko normatywne, które reguluje sposoby używania takich terminów jak: „wiedza” i „poznanie”. Wedle Leszka

\footnotetext{
${ }^{3}$ Lenartowicz [1984] s. 38.

4 Stróżewski [1984] s. 84-85.

5 Znaniecki [1922] s. 105.

6 Tamże, s. 104.
} 
Kołakowskiego jest to jedna z wielu form alienacji rozumu. Zatem racjonalność nie jest jakimś faktem, ale połączeniem określonych dążeń, którym podporządkowujemy się w naszym myśleniu, mówieniu, poznawaniu i działaniu. To łączenie określonych dążeń jest efektem refleksyjności rozumu, która umożliwia racjonalne przekraczanie standardów racjonalności.

Jak pokazuje H. Schnadelbach ${ }^{7}$ w eseju Rozum, może ów rozum być pojmowany jako: rozum subiektywny albo jako rozum obiektywny. Z kolei rozum subiektywny może mieć wiele odmian: od „operacyjnej” (prowadzącej od przesłanek do konkluzji) i intelektualnej (intuicyjny ogląd) po teoretyczną i praktyczną (z założeniem, że rozum w całości jest autorefleksyjnie krytyczny). Te rozróżnienia nie uchylają problemu historycznej przygodności rozumu ani jego językowego charakteru. Pozostaje także nierozwiązana kwestia rozumu obiektywnego.

Można rozum obiektywny określić jako sumę intelligibilnych, tj. uchwytnych przez intelekt struktur świata. Najlepiej zobrazował ten rodzaj rozumu Georg W. Hegel. Podstawową tezą jego systemu filozoficznego jest ta, która utożsamia myśl (absolut) z bytem. Człowiek jako podmiot poznania stwierdza „z jednej strony, że istnienie jest myślą, i ujmuje je pojęciowo, a z drugiej - na odwrót - odnajduje w swoim myśleniu istnienie" 8 . Mamy tutaj wyraźne utożsamienie myśli i bytu, co oznacza, że byt musi być identyczny z myślą, ponieważ realizuje tylko jej prawa. Byt tożsamy z myślą rozwija się w sposób logiczny i to właśnie stanowi korzenie heglowskiego racjonalizmu.

Racjonalizm ten opiera się na przekonaniu, że idea (rozum), poprzedzająca świat materialny, jest podłożem tego świata, myśl jest pierwotniejsza od przyrody (bytu materialnego). Świat materialny został wyłoniony z idei. Siłą stwórczą, która wyłoniła materię z myśli, jest rozum, a skoro poprzez rozum powstaje świat materialny, to prawa jego rozwoju są rozumne, logiczne. Zatem w świecie nie ma tajemnicy, wszystko jest rozumne i dzięki temu wszystko można poznać, ogarnąć ludzkim rozumem. Należy dodać: wszystko z wyjątkiem rozumu.

Autor Fenomenologii ducha nie przezwyciężył sceptycyzmu D. Hume’a. Nie jesteśmy w stanie uprawomocnić naszego sposobu poznawania, bowiem rozum nie może sam siebie uzasadnić. Wzorem Hegla trzeba go po prostu założyć, bowiem nie ma alternatywy do rozumu. Kryzys racjonalności polega na tym, że nastąpił wyraźny zwrot ku temu, co rozumowi obce, co jest nierozumne. Nie zmienia to jednak faktu, że rozum zdekonstruowany nadal jest jedynym prawo-

\footnotetext{
${ }^{7}$ Schnadelbach [1995]

${ }^{8}$ Hegel [1965] t. 1, s. 78.
} 
mocnym sposobem poznawania świata. Tym, co doprowadziło do dekonstrukcji rozumu/racjonalności, jest język.

\section{HORROR METAFIZYCZNY}

Nie sposób - pisze Leszek Kołakowski - wymknąć się z piekielnego kręgu epistemologii: cokolwiek powiemy choćby negatywnie o wiedzy - zakłada wiedzę, której zdobyciem się chełpimy; 'wiem, że nic nie wiem', wzięte dosłownie, jest wewnętrznie sprzeczne. 9

Nie ma zatem wiedzy czysto negatywnej. Wszelka wiedza jest pozytywna. Negacja bowiem, jak uczył Hegel, jest także określeniem ${ }^{10}$. Konsekwentnie rzecz biorąc, akt wątpienia zakłada wiarę, że coś jest prawdziwe, tyle że podmiot wątpiący nie wie, co mianowicie. Kiedy odrzuca się istnienie prawdy, wszelkie wątpienie staje się bezprzedmiotowe. Tak więc sceptycyzm jest stanowiskiem zarówno metafizycznym, jak i antymetafizycznym w podobnym sensie, $w$ jakim pozytywizm jest filozofią i antyfilozofią zarazem ${ }^{11}$.

Można przyjąć, że fundamentem metafizyki jest rozum, a religii wiara. Metafizyka, podobnie jak religia - o czym nauczał już Kołakowski w Obecności mitu stanowi odpowiedź na głębokie, egzystencjalne potrzeby człowieka, odpowiedź na pragnienie życia w świecie uporządkowanym, którego genezę, sens i przeznaczenie można uchwycić i określić w taki lub inny sposób. W tym sensie metafizyka jest wzorem doświadczenia kruchości egzystencji ludzkiej i dowodem na to, że nie wszystko można wiedzieć, a zatem w coś trzeba wierzyć. Rozum i wiara warunkują się, a ich zdekonstruowanymi przejawami są: sekularyzacja czy postmodernizm.

O tym jak rozum/racjonalność zdekonstruowała chrześcijaństwo pisał Max Weber, a dekonstrukcję rozumu/racjonalności przez język opisał Leszek Kołakowski w Horrorze metafizycznym. Jedną z głównych tez tej książki można zrekonstruować następująco: nie ma i być nie może powszechnie obowiązujących standardów racjonalności, nie istnieje coś takiego jak prawomocność epistemologiczna tout court. Prawda i fałsz są pochodne wobec przyjętego zespołu reguł, a te z kolei są ufundowane kulturowo. Nie ma absolutnego początku myślenia ani absolutnych kategorii pojęciowych. Nie jesteśmy w stanie wykroczyć poza język, a język

\footnotetext{
${ }^{9}$ Kołakowski [1990] s. 17.

10 Hegel [1967] s. 93 i nast.

${ }^{11}$ Kołakowski [1966] s. 7.
} 
nie może uwolnić się od swoich korzeni tkwiących w postrzeganiu, wyobraźni i logice norm kulturowych. Innymi słowy, realność przedmiotów jest zrelatywizowana do gry językowej, do przyjętych schematów percepcji, które kształtują sposób poznawczej organizacji świata, dzięki czemu żadna filozofia nie jest w stanie przezwyciężyć - paraliżującego ją - paradoksu samoodmienienia.

Czyniąc któryś z języków możliwych zdatnym do użytku i zrozumiałym - pisze Kołakowski - a zatem również czyniąc wiarygodnym jakiś metafizyczny czy epistemologiczny punkt widzenia - nigdy nie zaczynamy od początku. Wyboru spośród wszystkich języków możliwych dokonuje nie Bóg, lecz cywilizacja. Filozofowie wypowiadają ich aspiracje i wybory; nie oznacza to, że filozofowie są biernymi przekaźnikami czy fonograficznymi instrumentami, których cywilizacje używają jako swoich środków wyrazu (jak hegliści zdają się niekiedy wierzyć). Czyniąc cywilizację jawnie wypowiedzianą, filozofowie pomagają w jej ekspansji i utwierdzeniu, nie inaczej niż my wszyscy, którzy przez wysiłek ekspresji otwieramy nowe, niespodziewane drogi rozwoju nas samych. ${ }^{12}$

Według stanowiska zarysowanego powyżej istnieje fundamentalna i dwustronna zależność między kulturą tout court z jednej strony, a jej szczególnym segmentem, jakim jest filozofia, z drugiej. Filozofia - rzeczywistość myślowa zakorzeniona w kulturze - dziedziczy siłą rzeczy jej esprit i podstawowe cechy strukturalne. Ale nie tylko. Filozofia bowiem - przynajmniej częściowo - zwraca swój "dług" wobec kultury przyczyniając się do jej ekspansji i intelektualnego utwierdzania. Jeśli tak, to pluralizm i uderzające bogactwo myśli filozoficznej Zachodu jawi się jako strukturalne odzwierciedlenie pluralizmu i wewnętrznej złożoności tej cywilizacji. Jeśli tak, to wybitnie dyskursywny i racjonalistyczny charakter filozofii europejskiej wyrasta z kulturowo ufundowanego zaufania do ludzkich możliwości poznawczych i władzy Rozumu. Jeśli tak, to wreszcie sama filozofia może się ukonstytuować jako autonomiczna dziedzina ducha dopiero wówczas, gdy kultura wykroczy poza swój pierwotny stan przedliteracko-mityczny.

W tym kontekście dziwi Gellnerowska krytyka postmodernizmu jako mody, która przeminie. Autor Postmodernizmu uważa, że archaiczna jest lansowana przez postmodernistów sytuacja symetrii, w której odbywa się wszelka dyskusja i wymiana zdań.

Świat, który rzeczywiście zamieszkujemy - pisze - jest zupełnie inny. Być może około dwa i pół tysiąca lat temu przypominał on mniej więcej świat, który relaty-

${ }^{12}$ Kołakowski [1990] s. 120-121. 
wiści lubią odmalowywać. (...) Od tego czasu wyłoniła się pewna ilość kultur, wewnątrz których doszło do tego, że stosunek między tym co transcendentne, i tym co społeczne, stał się nieco bardziej napięty; to, co transcendentne, uwolniwszy się co najmniej od zbyt ewidentnej zależności od tego, co społeczne, zaczęło rościć sobie prawo do sądu nad tym ostatnim, nabrało autorytetu wykraczającego poza granice każdego społeczeństwa, każdego państwa i każdej grupy etnicznej. ${ }^{13}$

Zatem Gellner jest zwolennikiem Jaspersowskiego Wieku Osi, który jest skutkiem monoteizmu Starego Testamentu oraz greckiej filozofii idealnych form, czyli poglądu mówiącego, że kultura europejska jest syntezą judaizmu i greckiej filozofii.

Wielość i nieprzekładalność języków stanowi cechę konstytutywną filozofii w ogólności, a filozofii europejskiej w szczególności.

Filozofia - stwierdza Kołakowski - jest z definicji krainą pomieszania języków, tj. w której zgody, co do kryteriów prawomocności nie da się osiągnąć. (...) Tak więc potwierdza się, przynajmniej tak się zdaje, historia katastrofy babilońskiej: pomieszanie języków w filozofii jest karą za samo jej wynalezienie, czy też odwetem wziętym przez mitologię na oświeceniu za aroganckie próby jej unicestwienia. ${ }^{14}$

Jednym ze skutków dekonstrukcji mitologicznego obrazu świata, która w Europie dokonała się najpełniej i najkonsekwentniej, była problematyzacja i relatywizacja pojęcia prawdy. Rozwój filozofii zachodniej zaowocował wielością, równie prawomocnych, lecz wzajem nieprzekładalnych języków, i - co się z tym wiąże równie imponującą wielością prawd i fałszów. W ten sposób pojawił się Horror metaphysicus, wraz z widmem niekończącej się niepewności i w ten sposób pojawił się postmodernizm. Filozofia zachodu - dzięki podobieństwu cech strukturalnych - osiągnęła dynamikę analogiczną do tej, która stała się udziałem rozwiniętej kultury europejskiej: uruchomiła proces nieustannej samokrytyki i samokwestionowania.

\section{NAUKA I ETYKA}

Już Immanuel Kant pokazał, że wiedza jest moralnie neutralna a to, co podlega ocenie, to zastosowanie wiedzy. Zatem nauka nie zajmuje się wartościami, ale to nie oznacza, że „etyka zawiera prawdy, których nauka nie może ani udowodnić ani obalić"15. Zdaniem Bertranda Russella w ramach etyki możemy wskazać ob-

\footnotetext{
${ }^{13}$ Gellner [1990] s. 57.

${ }^{14}$ Kołakowski [1990] s. 135.

${ }^{15}$ Russell [2006] s. 138.
} 
szar reguł moralnych i obszar rozważań nad dobrem samym w sobie. Jak pokazały badania antropologów społecznych, możemy wskazać dwa źródła norm moralnych: religie i tradycje.

To kryterium posłużyło Ruth Benedict do skonstruowania typologii kultur. W pracy Chryzantemy i miecz wyróżnia „kultury winy" i „kultury wstydu”. Te pierwsze opierają się na koncepcji grzechu, wpajają jednostkom absolutne normy moralne i kładą nacisk na rozwój sumienia, te drugie absolutyzują pojęcie honoru i opinię publiczną.

Odpowiednie zachowanie człowieka w prawdziwych 'kulturach wstydu' - pisze Ruth Benedict - wynika z sankcji zewnętrznych, a nie, jak w prawdziwych 'kulturach winy' z wewnętrznego odczucia grzechu. Wstyd jest reakcją na krytykę ze strony innych. Człowiek wstydzi się, dlatego że otwarcie go wyszydzono i odrzucono. Sankcja jest bardzo silna. Wymaga ona jednak istnienia publiczności. Wina natomiast - nie. ${ }^{16}$

Poczucie winy jest następstwem negatywnej samooceny jednostki płynącej z uchybienia obowiązkom nałożonym na nią przez autorytet moralny. Źródło wstydu stanowi z kolei łamanie norm, które prowadzi do negatywnej oceny jednostki przez grupę. Wina jest odczuciem prywatnym, wstyd - faktem zewnętrznym. Te alternatywne systemy kontroli społecznej mają swoje ograniczenia, które może pokazać nauka.

Jeśli chodzi o sprawę wartości, to raczej leżą one poza domeną nauki. Zgadzam się z Russellem, że idea dobra i zła wiąże się z naszymi pragnieniami a nasze pragnienia bywają wzajemnie niezgodne. Etyka jest próbą przezwyciężenia tej subiektywności. Moim zdaniem, nie tylko tym. Istotę moralności stanowi odrzucenie przedmiotowego stosunku wobec innych ludzi, poszanowanie ich autonomii i podmiotowości, inaczej mówiąc: wzgląd na cudze dobro - dobro jednostki, grupy lub całego społeczeństwa. Nasze postępowanie będzie służyło interesowi społecznemu $\mathrm{w}$ tej mierze, $\mathrm{w}$ jakiej harmonizuje on $\mathrm{z}$ interesami indywidualnymi. „Zadaniem mądrych instytucji życia społecznego jest maksymalizacja tej harmonii (...). Każdy system etyki jest artykulacją pragnień ludzi, którzy go akceptują"17.

Emmanuel Mounier wiedział, że nauka dąży do zmniejszenia cierpienia. Jego krytyka chrześcijaństwa zaowocowała koncepcją osoby. „Osoba jest przeżywaną działalnością autokreacji, komunikacji i przynależności, którą daje się

\footnotetext{
16 Benedict [1999] s. 208.

${ }^{17}$ Russell [2006] s. 149.
} 
uchwycić i poznać w swoistym akcie jako ruch personalizacji"18. Pierwotnym doświadczeniem osoby jest doświadczenie drugiej osoby. Twórca personalizmu wychodzi ze stanowiska subiektywistycznego, rozpoczął analizę bytu ludzkiego od jednostkowego, myślącego „ja” i jak zauważa Tadeusz Pułżański: „(...) zamknął sobie z góry możliwość przejścia od 'ja' do 'ty'. Cogito w klasycznej kartezjańskiej postaci stanowi dowód istnienia jednostkowego myślącego podmiotu, nie zakłada natomiast istnienia innych podobnych myślących podmiotów"19. Myślę, że niekoniecznie. Kartezjusz stworzył podstawy do ujęcia myślenia jako zasady systemowej, którą Mounier nazwał „bezosobową myślą” i widział możliwość istnienia społeczności racjonalnej, opartej na zgodności umysłów w bezosobowej myśli i zgodności postępowania $\mathrm{w}$ formalnym porządku prawnym.

Personalizm chrześcijański wiąże byt osobowy z Bogiem. Pomiędzy bytem osoby ludzkiej i osoby boskiej zalega tajemnica transcendencji, którą Mounier rozumie dwojako: jako przekraczanie przez człowieka samego siebie oraz jako dążność do najwyższego istnienia. Wolność jest zaangażowaniem, tak jak u Heideggera odpowiedzialność, a egzystencja autentyczna tożsama jest $\mathrm{z}$ aktywnym uczestnictwem w świecie. Atrybutem osoby jest prawo wyboru, dlatego należy dążyć do poszerzania pola wolności. Godność bowiem to nic innego jak możliwość wyboru.

Ustalenia w obszarze etyki personalistycznej dotyczące uznania człowieczeństwa od początku są arbitralne (wywiedzione z normy transcendentnej) i nie uzasadnia ich nawet poczwórny argument, którego elementami są: przynależność gatunkowa (kryterium gatunkowe), kontynuacja rozwojowa, tożsamość i potencjalność (SCIP: Species, Continuity, Identity, Potentiality).

Kluczowy dokument watykańskiej Kongregacji Wiary definiuje metodę zapłodnienia in vitro jako "moralnie niegodziwą”, niezgodną z prawem natury, z prawem Bożym. Godziwe poczęcie dziecka ma miejsce wyłącznie w wyniku niepowtarzalnego miłosnego aktu małżeńskiego, bez ingerencji osób trzecich. Wynika z tego także i to, że moralnie niegodziwe jest poczęcie poza instytucją małżeństwa, o gwałcie nie wspominając. Skoro Kościół akceptuje te niegodziwie poczęte istnienia poza małżeństwem, to nic - poza doktrynalnym uporem - nie stoi na przeszkodzie, aby uznał i te poczęte in vitro.

Wracając do poczwórnego argumentu, to argument przynależności gatunkowej, nawet w minimalnym stopniu, nie potwierdza człowieczeństwa od począt$\mathrm{ku}$, bowiem sformułowanie, że ludzki embrion jest samoorganizującą się istotą,

\footnotetext{
18 Mounier [1960] s. 10.

${ }^{19}$ Pułżański [1967] s. 59.
} 
jest zdaniem egzystencjalnym a nie empirycznym. A jak wiadomo od dawna, tylko zdania empiryczne podlegają falsyfikacji, czyli sprawdzeniu w trybie naukowym. Można równie zasadnie twierdzić, że gameta męska lub żeńska to też „samoorganizująca się istota" należąca do gatunku homo sapiens. Tak się akurat składa, że potencjalność bytu nie jest tożsama z bytem, co niweczy siłę argumentu potencjalności. Kiedy Benedykt XVI mówi, że człowiek biotechnologią wkracza w gramatykę ustanowioną przez Boga nie będąc nim, to wpisuje się w myślenie strukturalistyczne. Kod genetyczny, to owa gramatyka pana Boga, tak jak język w analizie Ferdynanda de Saussera czy Noama Chomsky'ego. Jest on możliwością, potencjalnością, czyli obiektywnym systemem relacji pomiędzy znakami, który nie zależy od swoich fizycznych realizacji, ale przez akty mowy, czyli fizyczne realizacje się uobecnia. I nic nie pomogą argumenty w stylu, że mamy potentia obiectiva, czyli czysto teoretyczną możliwość zaistnienia jakiegoś wydarzenia i potentia subiectiva, oznaczającą możność uaktywnienia właściwego danej istocie potencjału, bowiem wtedy konsekwentnie musielibyśmy chronić komórki jajowe i plemniki. A to jest poza możliwościami człowieka. Dlatego, zarówno w bioetyce jak i w biojurysprudencji, konstruuje się takie pojęcie osoby, które umożliwia wyznaczanie etycznych i prawnych "granic" w rozwoju embrionu ludzkiego. Przyjmuje się w związku z tym, że moment personalizacji następuje wraz z implantacją embrionu lub jakiś czas po urodzeniu się człowieka, gdy możemy mówić o pojawieniu się świadomości.

Pozostałe dwa argumenty: ciągłości rozwojowej i tożsamości odwołują się do wyróżnionej pozycji człowieka w świecie, której nie da się drogą naukową uzasadnić, można ją jedynie założyć, a to i tak nie zneutralizuje stwierdzenia, że nie ma nic absurdalnego $\mathrm{w}$ stwierdzeniu, że świat jest absurdalny. $Z$ pewnością zwiększa jego siłę rażenia argument tożsamości, który brzmi: „człowiek jest przez cały czas swojej egzystencji tą samą, tożsamą z samą sobą istotą”. W tym miejscu trzeba wytoczyć działo, pod nazwą autoagresja immunologiczna, kiedy system odpornościowy człowieka wytwarza nadmierną ilość przeciwciał, które niszczą własny organizm na różnych poziomach jego funkcjonowania. Być może „jesteśmy chemiczną szumowiną w kosmosie", która wie, że wie. Kłopot w tym, że nie wie, czym jest to, co wie.

Leszek Kołakowski w pracy o Husserlu pokazuje mistrzowsko, że "gdy już staniemy na gruncie świadomości transcendentalnej, zauważamy, że ma ona zawsze do czynienia ze światem, który uczyniła świadomym. To, że świat jest 'sensem świata', ukonstytuowanym w świadomości; że pojęcie rzeczy samych w sobie jest absurdem; że tylko świadomość jest rzeczywistością w sobie ugruntowaną wszystko to u Husserla - to tylko warianty tradycyjnych argumentów idealizmu. 
Nie można myśleć o świecie, który nie jest myślany; gdy myślimy o rzeczy samej $\mathrm{w}$ sobie, staje się ona przedmiotem myśli, a zatem pojęcie rzeczy samej w sobie, rzeczy, która nie jest przedmiotem myśli, jest wewnętrznie sprzeczne. Argument ten nie jest do obalenia, ponieważ jest tautologią. Filozofia Husserla potwierdza zatem krytykę Gilsona (skierowaną pod adresem kartezjańczyków, kantystów i tych chrześcijańskich realistów, którzy naśladują Descartesa i Kanta):

(...) jeśli zaczynamy od immanentnego świata, tam też kończymy; gdy raz przyjmiemy idealistyczny sposób stawiania pytań, akceptujemy tym samym idealistyczne odpowiedzi. Idealizmu nie można przezwyciężyć na podstawie jego własnych pytań $(. . .)^{20}$,

nie ma poznawczego sensu rewitalizowanie przebrzmiałych etycznych koncepcji, w tym koncepcji etyki personalistycznej z jej poczwórnym argumentem. Wyzwaniom współczesności bardzo dobrze odpowiada etyka dyskursu, która odwołuje się do takiego sposobu uzasadniania norm i powinności, który może stanowić płaszczyznę możliwego porozumienia. Zasada dyskursu jest zarazem projekcją pewnego ładu społecznego, który zorientowany jest na zastępowanie walki i działań strategicznych, dyskusją i argumentacją. W tym sensie sama formalna zasada dyskursu ma charakter normatywny i jest projekcją pewnej doniosłej moralnie formy współżycia.

Doniosłość i zasadność etyki dyskursu można tłumaczyć także i tym, że stanowi ona jedną z bardziej trafnych odpowiedzi na sytuację, w jakiej i wobec której znalazła się nowożytna świadomość moralna. Po pierwsze, świadomość ta przeszła od myślenia moralnego w kategoriach „indywidualnego dążenia” (dążenia do dobra, do realizacji własnej doskonałości, własnej szczęśliwości), do myślenia w kategoriach „powinności” (normy, kategorycznego imperatywu czy bezwarunkowego obowiązywania). Po drugie zaś, porzuciła ona nietematyzowane zarówno w etyce antycznej, jak też wszelkich jej późniejszych kontynuacjach i przyjmowane poniekąd jako oczywiste, przeświadczenie, "że wymogi społeczności pokrywają się z prawdziwymi interesami jednostki" 21 . Rozpad metafizyczno-religijnego obrazu świata, jak też pluralizm tego rodzaju obrazów oraz pluralizm wyznaniowy w świecie zachodnim unicestwił możliwość jednoznacznego co do treści określenia tego, co jest „prawdziwym interesem jednostki”. Przemiany w rzeczywistości społeczno-kulturowej były istotnym czynnikiem wymuszającym

\footnotetext{
${ }^{20}$ Kołakowski [1987] s. 36.

${ }^{21}$ Kramer [1992] s. 9.
} 
przejście w myśleniu moralnym. Inaczej mówiąc: musiała się zmienić konieczna forma uspołecznienia, jaką jest moralność. Odpowiedzią na sytuację nowoczesnego świata, w którym nie jest już tak, że relacje pomiędzy jednostką a społeczeństwem są uregulowane przez utarty obyczaj, lecz regulacje te wymagają dopiero uzasadnienia i wspólnego zaakceptowania, jest etyka dyskursu. Jest to zarazem sytuacja, kiedy nie można narzucić innym celów, które miałyby być przedmiotem ich dążeń, można tylko ustanawiać normy współżycia i określać negatywnie, czego czynić nie wolno.

Przemiana w myśleniu moralnym polegała także i na tym, co wyraźnie widać w etyce formalnej Immanuela Kanta, że nastąpił rozdział pomiędzy tym, co reguluje prawo, a tym, co należy do obszaru ściśle pojętej moralności. Można powiedzieć, że mamy do czynienia z sytuacją uniwersalizacji prawa i indywidualizacji moralności. Faktyczne wyzwolenie jednostki spod dominacji tego, co społeczne, zwycięstwo indywidualizmu, zmusiło do postawienia pytania o sposób dochodzenia do wspólnych wyobrażeń, ocen i norm. Ale nie tylko. Zmienił się także sposób budowania własnej tożsamości, która przybrała formę powinności. Zgodnie z etyką dyskursu powinność, to nałożenie przymusu samemu sobie i samozobowiązanie, które o tyle tylko ma źródło poza podmiotem, że sam podmiot jest w stanie patrzeć na siebie z perspektywy „uogólnionego drugiego”, a zatem umie się rozdwoić i przez to patrzeć na siebie oczyma abstrakcyjnych innych.

Dla Jurgena Habermasa społeczność nie jest konkretną wspólnotą empiryczną, lecz idealną wspólnotą komunikacyjną. Odwołanie się do idealnej wspólnoty i do zasady dyskursu pozwala na ujęcie powinności jako samozobowiązania, które jednostka ma realizować własnym wysiłkiem. Można mieć uzasadnione wrażenie, że jest to wersja personalizmu bez Boga, która pozwala czuć się bezpiecznie w przestrzeni społecznej jednakowo dostępnej dla każdego.

\section{Bibliografia}

Benedict [1999] - R. Benedict, Chryzantemy i miecz, Warszawa 1999.

Dziki [2003] - J. Dziki, Dzieje życia na ziemi, Warszawa 2003.

Gellner [1990] - E. Gellner, Postmodernism, Cambridge 1990.

Hegel [1965] - G.W. Hegel, Fenomenologia ducha, Warszawa 1965.

Hegel [1967] - G.W. Hegel, Wykłady z filozofii dziejów, Warszawa 1967.

Kołakowski [1966] - L. Kołakowski, Filozofia pozytywistyczna (od Hume’a do Koła Wiedeńskiego), Warszawa 1966.

Kołakowski [1987] - L. Kołakowski, Husserl i poszukiwanie pewności, Warszawa 1987. 
Kołakowski [1990] - L. Kołakowski, Horror metaphysicus, Warszawa 1990.

Lenartowicz [1984] - P. Lenartowicz, Elementy filozofii zjawiska biologicznego, Kraków 1984.

Kramer [1992] - H. Kramer, Integrative Ethik, Frankfurt/M 1992.

Martens, Schnadelbach [1995] - Filozofia. Podstawowe pytania, E. Martens i H. Schnadelbach (red.), Warszawa 1995.

Mounier [1960] - E. Mounier, Personalizm, [w:] Wprowadzenie do egzystencjalizmu, Warszawa 1960.

Pułżański [1967] - T. Pułżański, Mounier, Warszawa 1967.

Ricoeur [1991] - P. Ricoeur, Osoba: struktura etyczna i moralna, [w:] Zawierzyć człowiekowi. Księdzu Józefowi Tischnerowi w sześćdziesiąte urodziny, Kraków 1991.

Russell [2006] - B. Russell, Religia i nauka, Warszawa 2006.

Schnadelbach [1995] - H. Schnadelbach, Rozum, [w:] Filozofia. Podstawowe pytania, E. Martens i H. Schnadelbach (red.), Warszawa 1995.

Stróżewski [1984] - W. Stróżewski, Dialektyka twórczości, Kraków 1984.

Znaniecki [1922] - F. Znaniecki, Wstęp do socjologii, Poznań 1922. 